\title{
Phytoprotection
}

\section{A modified leaf disk method for rearing predaceous mites [Acarina : Phytoseiidae]}

\section{J. Brodeur et C. Cloutier}

Volume 73, numéro 2, 1992

URI : https://id.erudit.org/iderudit/706021ar

DOI : https://doi.org/10.7202/706021ar

Aller au sommaire du numéro

Éditeur(s)

Société de protection des plantes du Québec (SPPQ)l

ISSN

0031-9511 (imprimé)

1710-1603 (numérique)

Découvrir la revue

Citer cet article

Brodeur, J. \& Cloutier, C. (1992). A modified leaf disk method for rearing predaceous mites [Acarina : Phytoseiidae]. Phytoprotection, 73(2), 69-72. https://doi.org/10.7202/706021ar
Résumé de l'article

La méthode du disque foliaire coupé pour élever des phytoséiides a été modifiée en maintenant le disque foliaire sur une solution nutritive solidifiée avec de l'agar. L'acarien prédateur Amblyseius cucumeris et sa proie, le thrips Frankliniella occidentalis, ont été élevés avec succès sur ce milieu. La survie et le temps de rétention du prédateur sur agar étaient meilleurs que sur de la ouate. L'agar a prolongé la qualité du feuillage pour la survie des larves de thrips comparé à la ouate et à l'eau, tout en offrant plusieurs autres avantages par rapport à ces milieux. 


\title{
A modified leaf disk method for rearing predaceous mites [Acarina: Phytoseiidae]
}

\author{
Jacques Brodeur and Conrad Cloutier ${ }^{1}$
}

Received 1992-01-20; accepted 1992-07-28

The detached leaf disk method for rearing phytoseiids was modified by maintaining leaf disks on a nutrient solution solidified with agar. The predaceous mite, Amblyseius cucumeris, and thrips prey, Frankliniella occidentalis, were successfully reared on cucumber leaf disks using this technique. Predator survival and retention time on agar as the leaf supporting medium were improved compared to cotton wool. Agar prolonged leaf disk quality for thrips survival compared to both cotton wool and water, while offering other significant advantages to these alternative media.

Brodeur, J., and C. Cloutier. 1992. A modified leaf disk method for rearing predaceous mites [Acarina: Phytoseiidae]. PHYTOPROTECTION 73: 69-72.

La méthode du disque foliaire coupé pour élever des phytoséiides a été modifiée en maintenant le disque foliaire sur une solution nutritive solidifiée avec de I'agar. L'acarien prédateur Amblyseius cucumeris et sa proie, le thrips Frankliniella occidentalis, ont été élevés avec succès sur ce milieu. La survie et le temps de rétention du prédateur sur agar étaient meilleurs que sur de la ouate. L'agar a prolongé la qualité du feuillage pour la survie des larves de thrips comparé à la ouate et à l'eau, tout en offrant plusieurs autres avantages par rapport à ces milieux.

\section{INTRODUCTION}

Rearing predaceous phytoseiids for experimental purposes is time consuming and requires constant precaution to avoid mite escape, species or strain contamination, prey contamination, and cannibalism. Various techniques for culturing and handling phytoseiids have been described in which the mites are either reared on artificial substrates, whole plants or excised plant parts (Helle and Overmeer 1985; Overmeer 1985). For the past 30 yrs, the detached leaf or leaf disk culture has been commonly used for rearing phytoseiid predators. A major advantage of this

1. Département de biologie, Centre de recherche en horticulture, Université Laval, Québec (Québec), Canada G1K 7P4 method is that prey remain in good condition and, in some cases, may reproduce. However, not all plant species are suitable because leaves may not last once excised (Overmeer 1985), and leaf supporting media (cotton wool, Cellucotton ${ }^{\circledR}$, polyurethane) do not always prevent escape of mites, prey and predators (Bonde 1989).

Mass cultures of Amblyseius cucumeris (Oudemans) are reared on alternative prey consisting of various species of mites (Ramakers and van Lieburg 1982). For experimental purposes, arenas consisting of leaf disks laid on wet cotton (Johnson 1990; Morewood and Gilkeson 1991) or floating on water (van der Hoeven and van Rijn 1990) have been used. Following unsatisfactory rearing of $A$. cucumerisand the western flower thrips Frankliniella occidentalis (Pergande) on cucumber leaf 
disks, we developed a modified leaf disk method using a nutrient solution solidified with agar as the leaf supporting medium. The modification was based on a technique originally designed to rear aphids (Milner 1981). Agar gel has apparently been used previously to assist rearing of phytoseiid mites (Osakabe 1988), but the procedure was not described.

This paper describes innovations made to the leaf disk method to rear A. cucumeris and thrips prey, and reports data collected on incidence of predator escape and survival on agar as compared to cotton wool and water.

\section{MATERIAL AND METHODS}

\section{Description of the modified leaf disk method}

Agarose (Anachemia, Lab-grade) at the rate of $8 \mathrm{~g} \mathrm{~L}^{-1}$ was added to 20:20:20 plant growth fertilizer diluted at a rate of $2 \mathrm{~g} \mathrm{~L}^{-1}$ of distilled water. The mixture is heated for $20 \mathrm{~min}$ at $121^{\circ} \mathrm{C}$ (1.4 bar). After cooling to $45-50^{\circ} \mathrm{C}$, a fungicide solution $(0.3 \mathrm{~g}$ a.i. of benomyl WP [methyl 1-(butylcarbamoyl)-2-benzimidazole carbamate], $7 \mathrm{~mL}$ of ethanol $99 \%$, and $3 \mathrm{~mL}$ of distilled water) is added at a rate of $1 \mathrm{~mL} \mathrm{~L}^{-1}$ of fertilized agar. The medium is then poured into large petri dishes $(14 \mathrm{~cm} \times 1.5$ $\mathrm{cm})$, and leaf disks (1 $\mathrm{cm}$ in diam) are deposited upper side down on the agar, leaving the natural feeding surface ex-

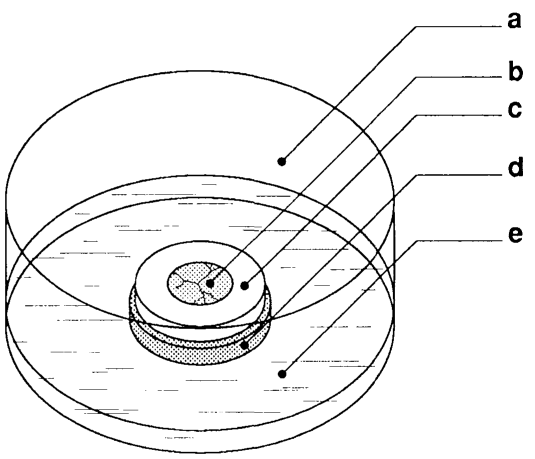

Figure 1. Phytoseiid rearing arena. (a) clear plastic petri dish bottom, (b) cucumber leaf disk, (c) fertilized agar disk, (d) disk of modelling clay, (e) water. posed to thrips prey. To further reduce contamination, leaves were first soaked for $3 \mathrm{~s}$ in a bleach solution (sodium hypochlorite [commercial $6.0 \%$ concentrate] diluted at a rate of $\left.3 \mathrm{~mL} \mathrm{~L}^{-1}\right)$. When solidified, the agar with a leaf disk on top is cut up into $2-\mathrm{cm}$ diameter disks, and placed on a $0.5-\mathrm{cm}$ thick disk of modelling clay affixed to the bottom of a small petri dish (60 mm $\times 20 \mathrm{~mm}$; Fig. 1). Finally, petri dish bottoms are half filled with distilled water to isolate the agar-leaf-clay islet, and a cover placed on top to maintain high relative humidity.

\section{Suitability of the modified leaf clisk method}

Amblyseius cucumeris was obtained from Koppert B.V. and Frankliniella occidentalis was collected from greenhouse cucumber. Leaf disks used in the tests were cut out of healthy mature cucumber leaves (Cucumis sativus L. cv. Corona) that had first been washed with distilled water. The tests were conducted in a growth chamber at $25 \pm 1{ }^{\circ} \mathrm{C}, 65-70 \% \mathrm{RH}$, and under a photoperiod of $16 \mathrm{~h}$ day and $8 \mathrm{~h}$ night.

Tests were designed to compare three leaf disk supporting media: fertilized agar, wet pad of (natural) cotton wool, and distilled water. In the second procedure, petri dishes were half filled with wet cotton wool, and leaf disks were placed in the centre of the arena. In the third procedure, leaf disks were floated on water and held in place with insect pins. Both in the cotton wool and water supporting media, fertilizer and fungicide were supplied daily to refresh these media.

Survival and tendency of $A$. cucumeris to escape were compared between treatments for a 6-d rearing test with both gravid females and immatures (larva, proto- and deutonymph). No additional barriers around the periphery of the leaf disks were used. This allowed free mite escape in response to decreasing overall quality of the three types of leaf environments provided within arenas. Two-dayold gravid females were placed in isolation on leaf disks, with eight first-instar nymphs (0-6h) of F. occidentalis renewed daily as food. In the case of immatures, newly hatched larvae of $A$. cucumeriswere placed individually on leaf disks, and provided daily with freshly killed thrips 
nymphs (head squashed), as $A$. cucumeris protonymphs have difficulty attacking nymphs of $F$. occidentalis (Johnson 1990; Sengonca and Bendiek 1988). A 25- $\mathrm{mm}^{2}$ piece of black cardboard placed on leaf disks provided mites with a shelter. Mites were transferred to fresh leaf disks midway through the 6-d test.

Survival of immatures was monitored every $24 \mathrm{~h}$ for $6 \mathrm{~d}$, i.e. through complete development. Survival of adult females was also monitored for $6 \mathrm{~d}$. We noted the position of dead mites in each type of arena (on leaf surface, agar, cotton wool, or in water). Tendency to escape was compared between the three media using retention time (minimum 0 , maximum 6 d), with individuals found dead on leaf disks being excluded from the analysis. Twenty replicate individuals were tested in each treatment. Escape data were analysed by ANOVA followed by TukeyKramer test (Sokal and Rohlf 1981), and survival data by a G-test followed by simultaneous test procedure (Gabriel 1966).

\section{RESULTS AND DISCUSSION}

Immatures and female adults $A$. cucumeris were retained significantly longer on cucumber disks placed on water, than on disks placed on cotton wool (Immatures: $F_{2,39}=4.48, P \leq 0.05$; Adults: $F_{2,36}=6.65$, $P \leq 0.05$; Table 1). Similar variation was observed with respect to the number of mites recovered alive at the end of the 6-d test on the three media (Immatures: $G_{2}=13.06, P \leq 0.05 ;$ Adults: $G_{2}=15.87, P \leq$ 0.05 ; Table 1). Of those mites (immature or adult) that escaped from cucumber disks, the proportions of individuals actually found trapped in agar or cotton wool, or drowned in water were $55 \%(n=$ $11), 61 \%(n=23)$ and $71 \%(n=7)$, respectively. Water surrounded agar, but not the agar itself, acts as a barrier to reduce escape of $A$. cucumeris. Although some mites died trapped on the agar surface, $A$. cucumeris was observed walking on agar.

Agar as a leaf supporting medium for rearing $A$. cucumeris on cucumber disks improves various aspects of the detached leaf method. Cucumber disks placed on fertilized agar remain in good condition for a relatively long period, which results in thrips prey being available to the predator for a longer period of time. Additional results on the survival of thrips larvae $3 \mathrm{~d}$ after being released on each media, and as a function of leaf disk age since being cut, indicated $72 \%$ survival on agarsupported leaf disks aged 6 to $9 \mathrm{~d}$, compared to only 3 and $8 \%$ on leaf disks supported by either cotton wool or water, respectively $(P \leq 0.01)$. Survival was still $54 \%$ on agar-supported leaves 12 to $15 \mathrm{~d}$ after cutting, compared to $0 \%$ on other media. Therefore, agar-supported leaf disks provided significantly more durable substrates for thrips than either cotton wool or water.

Table 1. Retention time and survival of immature stages and adult females of Amblyseius cucumeris in a 6-d rearing test on cucumber leaf disks supported on three different types of media

\begin{tabular}{|c|c|c|c|c|c|c|}
\hline \multirow[b]{2}{*}{ Medium } & \multicolumn{3}{|c|}{ Immature stages } & \multicolumn{3}{|c|}{ Adults } \\
\hline & $\overline{N^{a}}$ & $\begin{array}{l}\text { Retention } \\
\text { time }^{\mathrm{b}} \\
\text { (d) }\end{array}$ & $\begin{array}{c}\text { Survival } \\
(\%)\end{array}$ & $\bar{N}$ & $\begin{array}{l}\text { Retention } \\
\text { time } \\
\text { (d) }\end{array}$ & $\begin{array}{c}\text { Survival } \\
(\%)\end{array}$ \\
\hline Agar & 14 & $5.0 \pm 0.5 a b^{c}$ & $64.3 \mathrm{a}^{\mathrm{d}}$ & 14 & $5.0 \pm 0.4 a$ & $64.3 \mathrm{a}$ \\
\hline Cotton wool & 15 & $3.5 \pm 0.5 b$ & $13.3 \mathrm{~b}$ & 12 & $3.3 \pm 0.6 b$ & $16.7 \mathrm{~b}$ \\
\hline Water & 13 & $5.4 \pm 0.3 a$ & $69.2 \mathrm{a}$ & 13 & $5.6 \pm 0.4 a$ & $92.3 \mathrm{a}$ \\
\hline
\end{tabular}

\footnotetext{
a $\mathrm{N}$ is number of individuals tested.

b Mean \pm standard error.

c Means within columns followed by the same letter are not significantly different $(P>0.05)$.

d Percentages within columns followed by the same letter are not significantly different $(P>$ 0.05).
} 
There are several other advantages to the agar leaf disk method. The small units described allow mite examination under a microscope. Leaf disks placed on agar just before it sets fit the gel tightly, providing no holes where mites can be trapped. Agar also reduces the amount of water needed, and thus risk of spillage. Agar in covered petri dishes retains water, which thus needs to be added less frequently. Relative humidity remains high in the dish, favouring egg hatching. Agar may be stored for several weeks at $4^{\circ} \mathrm{C}$, and reused (if not contaminated). McMurtry and Scriven (1962) showed that Euseius hibisci (Chant) laid more eggs when agar containing yeast hydrolysate was available with tetranychid prey. Therefore, food supplements (e.g. yeast, honey, pollen) might be added to the agar leaf-supporting medium to provide alternative food for the phytoseiid, although more care should then be exerciced to avoid fungal growth. Finally, leaves supported on agar might also be useful for rearing mites upsidedown, a possibly more natural position.

Mite escape, always a problem in rearing and studying mites, is not completely prevented on agar, but as shown here for A. cucumeris, its use as a support in the detached leaf method introduces significant advantages for rearing these predators with live phytophagous prey. Although the method was originally developed for aphids (Milner 1981), our results reveal its potential for phytoseiid mites and thrips prey, and it should also prove useful for phytoseiids with tetranychid prey.

\section{ACKNOWLEDGEMENTS}

Thanks are due to Christiane Bussières, Chantal Breton and Josée Charbonneau for technical assistance. This work would not have been possible without the financial support of the Canada-Québec Agreement on Food and Agriculture Development.

\section{REFERENCES}

Bonde, J. 1989. Biological studies including population growth parameters of the predatory mite Amblyseius barkeri (Acarina:
Phytoseiidae) at $25^{\circ} \mathrm{C}$ in the laboratory. Entomophaga 34: 275-287.

Gabriel, K. R. 1966. Simultaneous test procedures for multiple comparisons on categorical data. J. Am. Stat. Assoc. 61: 10811096.

Helle, W., and W.P. J. Overmeer. 1985. Rearing techniques. Pages 331-335 in W. Helle and M. W. Sabelis (eds.), Spider mites, their biology, natural enemies and control. Vol. A, Elsevier, Amsterdam.

Johnson, S. G. 1990. Biology and predacious ability of Amblyseius barkeri (Hughes) and A. cucumeris (Oudemans)(Acarina: Fhytoseiidae), predators of the western flower thrips, Frankliniella occidentalis (Pergande)(Thysanoptera: Thripidae). M. Sc. Thesis. McGill University, Moritréal, Québec. 87 pp.

McMlurtry, J. A., and G. T. Scriven. 1962. The use of agar media in transporting and rearing phytoseiid mites. J. Econ. Entomol. 55: 412-414.

Milner, R. J. 1981. A modified leaf-disk method for rearing of aphids. Aust. Invertebr. Pathol. Newsl. 2: 46-47.

Morewood, W. D., and L. A. Gilkeson. 1991. Diapause induction in the thrips predator Amblyseius cucumeris (Acarina: Phytoseiidae) under greenhouse conditions. Entomophaga 36: 253-263.

Osakabe, M. 1988. Relationships between food substances and developmental success in Amblyseius sojaensis Ehara (Acarina: Phytoseiidae). Appl. Entomol. Zool. 23: 45-51.

Overmeer, W. P. J. 1985. Rearing and handling. Pages 161-170 in W. Helle and M. W. Sabelis (eds.), Spider mites, their biology, natural enemies and control. Vol. B, Elsevier, Amsterdam.

Ramakers, P. M. J., and M. J. van Lieburg. 1982. Start of commercial production and introduction of Amblyseius mckenziei Sch. \& Pr. (Acarina: Phytoseiidae) for the control of Thrips tabaci Lind. (Thysanoptera." Thripidae) in glasshouses. Meded. Fac. Landbouwwet. Rijksuniv. Gent 47: 541-545.

Sengonca, C., and J. Bendiek. 1988. Die eignung zweier raubmilbenarten zur biologischen bekämpfung von Frankliniella occidentalis (Pergande) (Thysanoptera: Thripidae). Nachrichtenbl. Dtsch. Pflarizenschutzdienst (Berl.) 40: 171-175.

Sokal, R. R., and F. J. Rohlf. 1981. Biometry: the principles and practice of statistics in biological research. 2nd ed. W.H. Freeman Company, New York. 859 pp.

van der Hoeven, W. A. D., and P. C. J. van Rijn. 1990. Factors affecting the attack success of predatory mites on thrips larvae. Proc. Exp. Appl. Entomol. 1: 25-30. 